\title{
New vectors in northern Sarawak, Malaysian Borneo, for the zoonotic malaria parasite, Plasmodium knowlesi
}

\author{
Joshua X. D. Ang ${ }^{1}$ (1), Khamisah A. Kadir ${ }^{1}$, Dayang S. A. Mohamad' ', Asmad Matusop², Paul C. S. Divis',
} Khatijah Yaman ${ }^{1}$ and Balbir Singh ${ }^{1 *}$

\begin{abstract}
Background: Plasmodium knowlesi is a significant cause of human malaria in Sarawak, Malaysian Borneo. Only one study has been previously undertaken in Sarawak to identify vectors of P. knowlesi, where Anopheles latens was incriminated as the vector in Kapit, central Sarawak. A study was therefore undertaken to identify malaria vectors in a different location in Sarawak.

Methods: Mosquitoes found landing on humans and resting on leaves over a 5-day period at two sites in the Lawas District of northern Sarawak were collected and identified. DNA samples extracted from salivary glands of Anopheles mosquitoes were subjected to nested PCR malaria-detection assays. The small subunit ribosomal RNA (SSU rRNA) gene of Plasmodium was sequenced, and the internal transcribed spacer 2 (ITS2) and mitochondrial cytochrome $c$ oxidase subunit 1 (cox1) gene of the mosquitoes were sequenced from the Plasmodium-positive samples for phylogenetic analysis.

Results: Totals of 65 anophelines and 127 culicines were collected. By PCR, 6 An. balabacensis and 5 An. donaldi were found to have single $P$. knowlesi infections while 3 other An. balabacensis had either single, double or triple infections with P. inui, P. fieldi, P. cynomolgi and P. knowlesi. Phylogenetic analysis of the Plasmodium SSU rRNA gene confirmed 3 An. donaldi and 3 An. balabacensis with single P. knowlesi infections, while 3 other An. balabacensis had two or more Plasmodium species of P. inui, P. knowlesi, P. cynomolgi and some species of Plasmodium that could not be conclusively identified. Phylogenies inferred from the ITS2 and/or cox 1 sequences of An. balabacensis and An. donaldi indicate that they are genetically indistinguishable from An. balabacensis and An. donaldi, respectively, found in Sabah, Malaysian Borneo.
\end{abstract}

Conclusions: Previously An. latens was identified as the vector for P. knowlesi in Kapit, central Sarawak, Malaysian Borneo, and now An. balabacensis and An. donaldi have been incriminated as vectors for zoonotic malaria in Lawas, northern Sarawak.

Keywords: Zoonosis, Malaria, Plasmodium knowlesi, Vector, Anopheles balabacensis, Anopheles donaldi

*Correspondence: bsingh@unimas.my

${ }^{1}$ Malaria Research Centre, Faculty of Medicine \& Health Sciences,

Universiti Malaysia Sarawak, Kuching, Sarawak, Malaysia

Full list of author information is available at the end of the article

(c) The Author(s) 2020. This article is licensed under a Creative Commons Attribution 4.0 International License, which permits use, sharing, adaptation, distribution and reproduction in any medium or format, as long as you give appropriate credit to the original author(s) and the source, provide a link to the Creative Commons licence, and indicate if changes were made. The images or other third party material in this article are included in the article's Creative Commons licence, unless indicated otherwise in a credit line to the material. If material is not included in the article's Creative Commons licence and your intended use is not permitted by statutory regulation or exceeds the permitted use, you will need to obtain permission directly from the copyright holder. To view a copy of this licence, visit http://creativeco mmons.org/licenses/by/4.0/. The Creative Commons Public Domain Dedication waiver (http://creativecommons.org/publicdomain/ zero/1.0/) applies to the data made available in this article, unless otherwise stated in a credit line to the data. 